\title{
PENGARUH PERBEDAAN WAKTU PENANGKAPAN DAN LAMA WAKTU PENARIKAN TERHADAP KOMPOSISI HASIL TANGKAPAN PADA ALAT TANGKAP BAGAN PERAHU DI PERAIRAN DEMAK
}

\section{THE EFFECT OF TIME DIFFERENCES AND HAULING DURATION TOWARDS BOAT LIFT NETS FISHING CATCH IN DEMAK WATERS}

\author{
Herry Boesono*, Kukuh Eko Prihantoko, Intan Rosari Manalu, \& Agus Suherman \\ Program Studi Perikanan Tangkap, Fakultas Perikanan dan Ilmu Kelautan, \\ Universitas Diponegoro, Semarang, 50275, Indonesia \\ E-mail: herryboesono@gmail.com
}

\begin{abstract}
Demak had two fish auction which is still active, namely Morodemak and Wedung. Based on survey results in Morodemak Coast Fishing Port Demak, there are boat lift nets totaled 69 units. Fishers use boat lift nets of fishing gear in Morodemak waters to catch anchovy (Stolephorus sp.). This study aimed to analyze the composition of fishing results, analyze the effect of time differences on the fishing results, and analyze the effect of Hauling duration towards boat lift nets catches. The method used in this study is descriptive, and the data collection method consists of observation, interviews, literature study, and documentation. In this research, there were ten times of Boat Lift Nets fishing trip. The results are that the total weight of catches at 18.30-22.30 was 4,487.82 $\mathrm{Kg}$ less than the total weight of catches at 24.00-04.00, which was 6,563.18 Kg. The total weight of catches on 20-27.5 minutes Hauling is 6,601.9 Kg greater than The total weight of catches on 27.6-35 minutes Hauling is 4,449.1 $\mathrm{Kg}$. Based on the results, there are significant effects between fishing catch duration on the Hauling process towards boat lift nets catches, which can be operated continually at Demak waters.
\end{abstract}

Keywords: boat lift nets, fishing catches, hauling duration, time differences

\begin{abstract}
ABSTRAK
Kabupaten Demak memiliki dua tempat pelelangan ikan (TPI) yang masih aktif, yaitu TPI Morodemak dan TPI Wedung. Berdasarkan hasil survei di Pelabuhan Perikanan Pantai Morodemak Kabupaten Demak terdapat alat tangkap bagan perahu berjumlah 69 unit. Alat tangkap bagan perahu digunakan oleh para nelayan di perairan Demak untuk menangkap ikan teri (Stolephorus sp.). Penelitian ini bertujuan untuk menganalisis komposisi hasil tangkapan, menganalisis pengaruh waktu yang berbeda terhadap ikan hasil tangkapan dan menganalisis pengaruh lama penarikan yang berbeda terhadap ikan hasil tangkapan. Metode yang digunakan dalam penelitian ini adalah metode deskriptif dan untuk metode pengumpulan data terdiri atas observasi, wawancara, studi pustaka, dan dokumentasi. Penelitian ini dilakukan sebanyak 10 trip penangkapan dengan mengoperasikan alat tangkap bagan perahu. Hasil penelitian menunjukkan bahwa jumlah tangkapan pada jam 18.30-22.30 yaitu $4.487,82 \mathrm{Kg}$ lebih sedikit jika dibandingkan dengan jumlah tangkapan pada jam 24.00-04.00 yaitu $6.563,18 \mathrm{Kg}$. Hasil tangkapan dengan lama penarikan 20-27,5 menit yaitu 6.601,9 Kg lebih besar jika dibandingkan dengan hasil tangkapan dengan lama penarikan 27,6-35 menit yaitu 4.449,1 Kg. Variabel waktu penangkapan dan lama penarikan memiliki pengaruh terhadap hasil tangkapan nelayan bagan perahu, sehingga dapat dioperasikan di Perairan Demak.
\end{abstract}

Kata kunci: bagan perahu, hasil tangkapan, lama penarikan, waktu penangkapan

\section{PENDAHULUAN}

Bagan perahu atau yang biasa disebut boat lift net merupakan alat tangkap yang berbentuk persegi empat dengan panjang dan lebar yang sama. Bagian-bagian bagan perahu ini terdiri dari jaring, bambu, pipa besi, tali temali, lampu dan kapal ber- 
mesin. Bagian jaring dari bagan ini terbuat dari bahan waring yang dibentuk menjadi kantong. Bagian kantong terdiri dari lembaran-lembaran waring yang dirangkai atau dijahit sedemikian rupa sehingga dapat membentuk kantong berbentung bujur sangkar yang dikarenakan adanya kerangka yang dibentuk oleh bambu dan pipa besi (Sudirman \& Mallawa, 2004).

Bagan perahu (boat lift nets) adalah alat penangkap ikan yang dioperasikan dengan cara diturunkan ke kolom perairan dan diangkat kembali setelah banyak ikan di atasnya, dalam pengoperasiannya menggunakan perahu untuk berpindah-pindah ke lokasi yang diperkirakan banyak ikan. Bagan perahu diklasifikasikan ke dalam kelompok jaring angkat (lift nets) (Subani \& Barus, 1989).

Bagan perahu banyak digunakan oleh para nelayan di wilayah perairan Morodemak untuk menangkap ikan karena mempunyai beberapa keunggulan. Keunggulan tersebut antara lain: (1) Secara teknis mudah dilakukan (khususnya bagan tancap); (2) investasinya terjangkau oleh masyarakat; (3) merupakan perikanan rakyat yang telah digunakan oleh masyarakat di wilayah pesisir dan sekitar pulau-pulau kecil secara turun-temurun; (4) hasil tangkapannya selalu ada walaupun terkadang jumlahnya sedikit; (5) dari kapal menyerap banyak tenaga kerja; (6) dan teknologinya sangat sederhana.

Teknologi penangkapan ikan dengan bagan perahu menggunakan alat bantu cahaya lampu di kenal sebagai light fishing. Sumber cahaya yang digunakan mulai dari obor, lampu petromaks (lampu tekan minyak tanah) dan lampu listrik (Wisudo et al., 2001). Penggunaan cahaya lampu dimaksudkan untuk menarik dan mengkonsenterasikan kawanan ikan pada areal pencahayaan dan catchtable area bagan. Selain itu intensitas cahaya lampu sangat menentukan terhadap illuminasi cahaya dari lampu yang masuk ke dalam air. Prinsip penangkapan pada alat tangkap bagan adalah dengan memanfaatkan tingkah laku ikan, yaitu respons ikan terhadap cahaya utama pada ikan-ikan yang bersifat fototaksis positif. Metode operasi penangkapan tidak banyak perbedaan dengan daerah lain di Indonesia. Perbedaan yang terlihat adalah teknik dan taktik penangkapan.

Potensi sumber daya ikan disuatu wilayah haruslah dimanfaatkan secara optimal. Salah satu cara untuk memanfaatkan sumber daya ikan tersebut adalah dengan cara melakukan kegiatan penangkapan ikan. Kegiatan penangkapan ikan dapat dilakukan dengan menggunakan berbagai jenis alat tangkap ikan yang sudah berkembang. Bagan perahu merupakan salah satu jenis alat tangkap yang digunakan nelayan di Perairan Demak dengan hasil tangkapan utamanya adalah ikan teri, sedangkan hasil tangkapan sampingannya adalah cumi-cumi dan ikan pepetek. Dalam kegiatan penangkapan ikan dengan menggunakan alat tangkap bagan perahu, penentuan waktu penangkapan dan lama penarikan diduga dapat menjadi salah satu faktor yang berpengaruh terhadap jumlah hasil tangkapan. Berdasarkan penelitian Julian (2014), jenis organisme yang tertangkap pada setiap waktu penangkapan berbeda. Waktu penangkapan pertama antara pukul 18.0021.00 diperoleh hasil tangkapan sebanyak $58,3 \mathrm{Kg}$ atau sebesar $34,89 \%$ dari seluruh hasil tangkapan, waktu penangkapan kedua 21.00-00.00 WIB diperoleh hasil tangkapan sebesar 42,9 Kg atau sekitar 25,67\%, waktu penangkapan ketiga 00.00-03.00 WIB sebesar 32,1 Kg atau sekitar 19,21\% dan waktu penangkapan keempat 03.00-06.00 sebesar $33,8 \mathrm{Kg}$ atau sekitar 20,23\% dari total hasil tangkapan. Berat tangkapan tertinggi terjadi pada selang waktu penangkapan pertama antara pukul 18.00-21.00 WIB. Sedangkan berdasarkan penelitian Fauziyah et al. (2013) menunjukkan hasil bahwa rataan hasil tangkapan tertinggi diperoleh pada periode waktu hauling tengah malam (00.00-02.59 WIB) dimana hasilnya mencapai 2-3 kali lipat dari periode sebelum 
maupun sesudah tengah malam pada kategori total hasil tangkapan dan tangkapan ikan teri. Periode waktu hauling tengah malam adalah waktu paling optimal untuk mengoperasikan bagan tancap di perairan Sungsang. Banyaknya hasil tangkapan ikan teri pada periode Hauling tengah malam mengindikasikan banyaknya frekuensi kemunculan ikan di catchable area bagan tancap dan ikan telah beradaptasi dengan sempurna. Dilihat dari hasil penelitian kedua sumber terdapat perbedaan kesimpulan, maka dari itu diperlukannya penelitian lebih lanjut agar dapat melihat hasil terbaik diantara perbandingan waktu penangkapan tersebut.

Keberhasilan usaha penangkapan tergantung pada kecepatan dan ketepatan waktu penarikan jaring (hauling). Disini penggulung (roller) yang berfungsi sebagai penarik jaring memegang peranan yang sangat besar. Kecepatan hauling yang tinggi sangat diperlukan pada operasi penangkapan bagan. Faktor kecepatan ini sangat berpengaruh karena gerombolan ikan (schooling fish), namun walaupun kecepatan hauling tinggi tetapi apabila saat penarikan diiringi dengan seringnya terjadi hentakan-hentakan maka gerombolan ikan juga akan menyebar kembali. Hal ini disebabkan oleh timbulnya gelombanggelombang air yang dibutuhkan oleh pergerakan tali ataupun waring saat ditarik ke atas (Mohammad et al, 1999).

Tujuan dari penelitian ini adalah untuk menganalisis komposisi ikan hasil tangkapan bagan perahu di Perairan Demak, menganalisis pengaruh waktu yang berbeda terhadap ikan hasil tangkapan bagan perahu di Perairan Pantai Demak dan menganalisis pengaruh lama penarikan yang berbeda terhadap ikan hasil tangkapan Bagan Perahu di Perairan Demak.

\section{METODE PENELITIAN}

Penelitian ini dilaksanakan pada bulan Mei 2019. Lokasi penelitian di per- airan pantai utara Jawa Tengah, lebih tepatnya berada di perairan laut sekitar wilayah Morodemak, Kabupaten Demak.

Materi dalam penelitian ini adalah tentang waktu penangkapan ikan dan lama waktu penarikan terhadap hasil tangkapan pada alat tangkap Bagan Perahu. Metode penelitian yang digunakan dalam penelitian ini adalah metode deskriptif. Berdasarkan penelitian Sugiyono (2007), metode deskriptif merupakan jenis studi kasus yang mempunyai keunggulan sebagai suatu studi untuk mendukung studi yang besar di kemudian hari. Studi kasus dapat memberikan hipotesa-hipotesa untuk penelitian lanjutan. Jenis data yang digunakan dalam penelitian meliputi:

\subsection{Data Primer}

Data lokasi penangkapan diperoleh dengan menggunakan Global Positioning System (GPS); sedangkan data primer yang meliputi waktu penangkapan dan lama waktu penarikan jaring diperoleh dengan cara pengukuran langsung di lapangan dengan menggunakan jam dan stopwatch. Jumlah hasil tangkapan bagan perahu dicatat secara langsung. Pengambilan data in-situ waktu penangkapan dan lama waktu penarikan jaring pada kegiatan penangkapan bagan perahu dilakukan secara purposive sampling. Metode purposive sampling, yaitu metode sampling data dengan pertimbangan mewakili sampel wilayah tersebut, dengan pertimbangan fenomena yang ada di wilayah tersebut.

\subsection{Data Sekunder}

Data Sekunder yang diperoleh dari Dinas Kelautan dan Perikanan Kabupaten Demak, meliputi jumlah dan nilai produksi perikanan tahun 2018, jumlah armada penangkapan tahun 2018, jumlah alat tangkap tahun 2018 dan jumlah nelayan tahun 2018.

\subsection{Analisis Data}

Setelah data tersebut dikumpulkan, kemudian dianalisis dengan menggunakan 
metode analisis statistik dengan bantuan software SPSS Statistics 22.0.

Berdasarkan penelitian Sumanto (2014), uji persyaratan analisis diperlukan untuk mengetahui apakah analisis data untuk pengujian hipotesis dapat dilanjutkan atau tidak. Analisis ragam mempersyaratkan bahwa data berasal dari populasi yang berdistribusi normal dan kelompok-kelompok yang dibandingkan homogen. Oleh karena itu, dilakukan beberapa pengujian sebagai persyaratan analisis, yaitu: Uji Normalitas, Uji Homogenitas, Uji F (Simultan), dan Uji $\mathrm{t}$ (parsial).

\section{HASIL DAN PEMBAHASAN}

Perairan Demak mempunyai panjang pantai $\pm 34,1 \mathrm{~km}$ dengan luas perairan $\pm 254,61 \mathrm{~km}^{2}$. Pantai Perairan Demak seperti pada umumnya daerah Pantai Utara Jawa merupakan pantai yang landai, dangkal, ombak relatif kecil dan arus tidak begitu kuat. Dasar perairan terdiri dari lumpur tebal muara dan semakin ke tengah akan semakin menipis serta di beberapa tempat dasarnya terdiri dari pasir dan lumpur (Dinas Kelautan dan Perikanan Demak, 2012). Kabupaten Demak terdiri dari 11 Kecamatan, perikanan tangkap berkembang di 4 Kecamatan yaitu Kecamatan Karang Tengah, Sayung, Bonang dan Wedung. Secara keseluruhan di Kabupaten Demak terdapat 5 TPI yaitu TPI Karang Tengah, TPI Sayung, TPI Morodemak, TPI Bungo dan TPI Wedung. Sekarang hanya 2 TPI yang masih aktif yaitu TPI Morodemak dan TPI Wedung. Tempat Pelelangan Ikan Morodemak terletak di Komplek PPP Morodemak, Desa Purworejo, Kecamatan Bonang, Kabupaten Demak. Konstruksi bangunan TPI Morodemak terdiri dari kantor dan tempat lelang berada di depannya. Kondisi jalan TPI di PPI Morodemak adalah jalan aspal. Komoditas di TPI Morodemak, Kabupaten Demak adalah ikan teri, udang, kembung, tongkol, juwi, cumi-cumi, dan lain-lain. Sedangkan alat tangkap yang digunakan adalah purse seine, trammel net, gillnet, arad, bubu/jebat, dan bagan. Alat tangkap Bagan perahu melakukan trip setiap hari/one day fishing dengan jumlah ABK sebanyak 8-10 orang.

Bagan perahu (boat lift net) adalah penangkap ikan yang dioperasikan dengan cara diturunkan ke kolom perairan kemudian diangkat kembali setelah banyak ikan berkumpul diatasnya. Dalam pengoperasiannya bagan perahu menggunakan perahu untuk berpindah-pindah ke lokasi yang diperkirakan banyak ikannya. Bagan perahu diklasifikasikan ke dalam kelompok jaring angkat (lift net). Unit penangkapan bagan perahu yang digunakan di Perairan Demak terdiri dari 2 unit perahu, yaitu 1 unit perahu digunakan untuk menarik alat tangkap bagan perahu menuju fishing ground serta membawa hasil tangkapan ke fishing base dan 1 unit perahu terpasang pada bagan. Secara umum alat tangkap bagan perahu terdiri dari perahu, pelataran, rumah bagan, jaring, jangkar, pemberat jaring, katrol (pengulung tali), kawat, tiang utama, genset dan lampu (Figure 1). Ber-

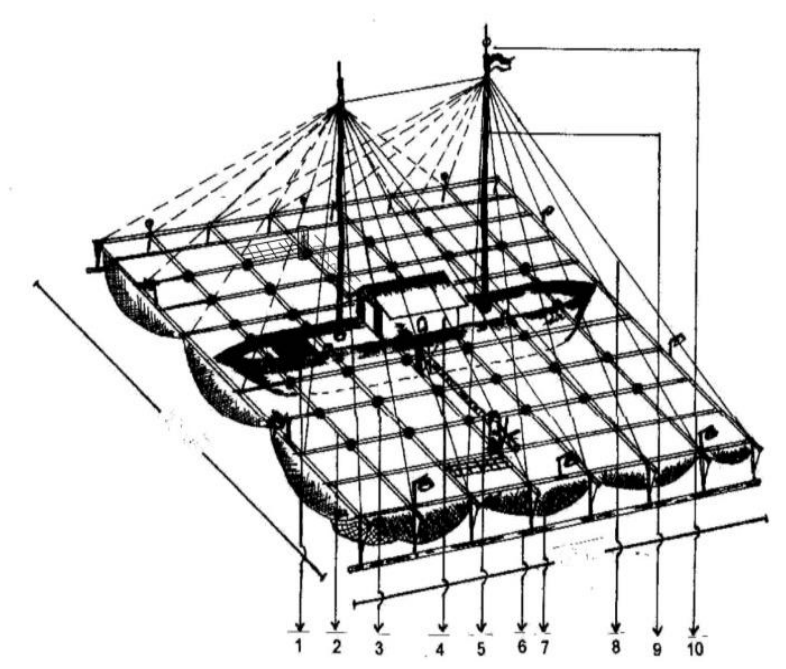

Figure 1. Boat Lift Net $(1=$ boat; $2=$ frame; $3=$ lamp; $4=$ housework; $5=$ roller; $6=$ balance $; 7=$ net $; 8=$ wire; $9=$ main mast $; 10=$ antenna). 
dasarkan penelitian yang dilakukan oleh Subani \& Barus (1989), secara umum konstruksi unit penangkapan bagan perahu terdiri atas kerangka kayu, waring, atau jaring (dari bahan polyethylene) serta perahu bermotor sebagai alat transportasi di laut.

\subsection{Komposisi Hasil Tangkapan}

Hasil tangkapan utama bagan perahu di perairan Demak adalah ikan teri (Stolephorus spp.). Ikan teri merupakan ikan yang mempunyai sifat fototaksis positif dan yang bersifat menggerombol, sehingga sangat menguntungkan bila ditangkap dengan menggunakan alat tangkap bagan perahu. Jenis ikan lain yang tertangkap saat pengoperasian bagan perahu ini diantaranya Ikan Tembang/Juwi (Sardinella gibbosa), Cumi-Cumi (Loligo sp.), Ikan Kembung (Rastrelliger negletus), Ikan Selar (Selaroides leptolepis), Ikan Layur (Trichiurus lepturus). Jumlah hasil tangkapan setiap kali dilakukan hauling berbeda-beda. Namun jenis ikan yang tertangkap setiap kali hauling hampir sama. Menurut Hasan (2008) dalam proses penangkapan ikan dengan bagan, atraktor cahaya yang digunakan bertujuan untuk mengumpulkan ikan yang mempunyai sifat fototaksis positif. Ikan yang bersifat fototaksis positif akan berkumpul di daerah cahaya lampu, sehingga memudahkan nelayan dalam melakukan upaya penangkapan. Ikan hasil tangkapan bagan perahu secara keseluruhan dapat dilihat pada Table 1.

Pada Table 1 terlihat bahwa hasil tangkapan terdiri dari hanya 1 spesies, yaitu ikan teri (Stolephorus spp.) dengan berat $5.939 \mathrm{Kg}$. Hasil tangkapan bycatch terdiri dari 5 spesies dengan berat total $5.190 \mathrm{Kg}$, masing-masing ikan Tembang/Juwi ( $S$. gibbosa) sebanyak $3.851 \mathrm{Kg}$, Cumi-Cumi (Loligo sp.) sebanyak 89,5 Kg, Ikan Kembung (R. negletus) sebanyak $462 \mathrm{Kg}$, Ikan Selar (S. leptolepis) sebanyak $845 \mathrm{Kg}$, dan Ikan Layur (T. lepturus) sebanyak 64,5 $\mathrm{Kg}$. Hasil tangkapan dalam kategori berat untuk tiap spesies ikan didominasi oleh ikan pelagis kecil. Hal ini disebabkan karena alat tangkap bagan perahu itu sendiri dalam pengoperasiannya menggunakan cahaya lampu sebagai daya tarik untuk mengumpulkan gerombolan ikanikan yang menyukai cahaya (phototaxis) ke dalam suatu area penangkapan. Menurut Junaidi et al. (2001), ikan-ikan pelagis yang tertangkap oleh bagan perahu selama penelitian yaitu Cumi-cumi (Loligo sp.), Layang (Decapterus russelli), Teri (Stelephorus commersonii), Kembung Lelaki ( $R$. kanangurta), Tembang ( $S$. fimbriata), Pepetek (Leiognathus splendens), Tongkol (Auxis thzard).

Table 1. Overall catch composition.

\begin{tabular}{llr}
\hline Classification & \multicolumn{1}{c}{ Name } & $\begin{array}{c}\text { Weight } \\
(\mathrm{Kg})\end{array}$ \\
\hline Target catch & Stolephorus spp. & 5.739 \\
Bycatch & S. gibbosa & 3.851 \\
& Loligo sp. & 89,5 \\
& R. negletus & 462 \\
& S. leptolepis & 845 \\
& T. lepturus & 642 \\
\hline Total & & 11.051 \\
\hline
\end{tabular}

Menurut Manggabarani et al. (2011), kedalaman air berpengaruh terhadap jumlah spesies, dan diduga faktor lingkungan sangat memengaruhi jumlah hasil tangkapan, di mana semakin dalam suatu perairan maka semakin banyak jumlah spesies yang dapat tertangkap. Faktor lainnya yaitu tingkah laku ikan yang senang dengan cahaya, dimana ada ikan yang bersifat phototaxsis seperti ikan teri. Rata-rata ikan akan berkumpul ketika lampu sudah dinyalakan selama 1-2 jam. Komposisi dalam kategori berat hasil tangkapan tiap spesies ikan dapat dilihat pada Figure 2.

Figure 2 merupakan komposisi hasil tangkapan dalam kategori berat yang secara keseluruhan hasil tangkapan didominasi oleh tangkapan target catch dengan berat sebesar $5.939 \mathrm{Kg}$ (53\%) dan bycatch 


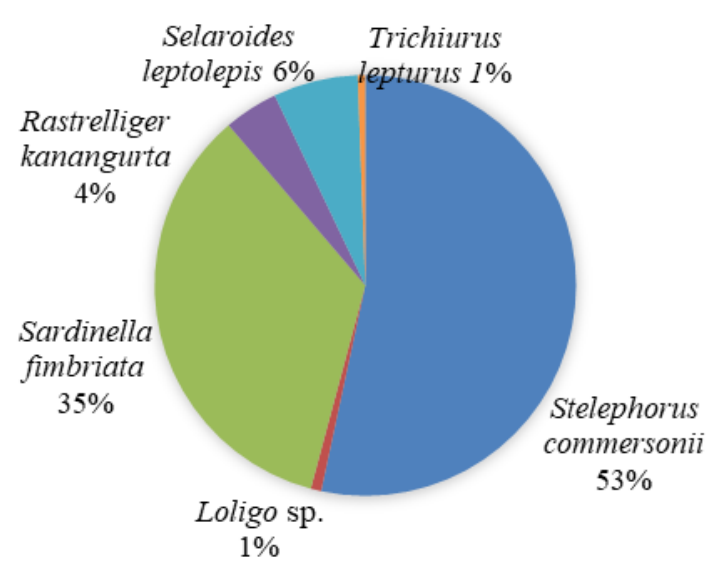

Figure 2. a graph of the catch composition.

sebanyak 5 spesies ikan dengan berat sebesar $5.190 \mathrm{Kg}(47 \%)$.

Menurut Wisudo et al. (2001), teknologi penangkapan ikan dengan bagan perahu menggunakan alat bantu cahaya lampu dikenal sebagai light fishing. Sumber cahaya yang digunakan mulai dari obor, lampu petromaks (lampu tekan minyak tanah) dan lampu listrik. Penggunaan cahaya lampu dimaksudkan untuk menarik dan mengkonsentrasikan kawanan ikan pada areal pencahayaan dan catchtable area bagan. Selain itu intensitas cahaya lampu sangat menentukan illuminasi cahaya dari lampu yang masuk ke dalam air. Prinsip penangkapan pada alat tangkap bagan adalah dengan memanfaatkan tingkah laku ikan, yaitu respons ikan terhadap cahaya utama pada ikan-ikan yang bersifat fototaksis positif. Metode operasi penangkapan tidak banyak perbedaan dengan daerah lain di Indonesia. Perbedaan yang terlihat adalah teknik dan taktik penangkapan.

\subsection{Perbedaan Waktu Penangkapan terhadap Hasil Tangkapan}

Hasil mengenai perbedaan waktu penangkapan terhadap hasil tangkapan dapat dilihat pada Table 2. Pengambilan sampel dilakukan sebanyak 10 kali pengulangan dengan hasil yang berbeda-beda di setiap

Table 2. Difference in catching time for cathes.

\begin{tabular}{|c|c|c|c|}
\hline \multirow{2}{*}{ Trip } & \multirow{2}{*}{ Repitition } & \multicolumn{2}{|c|}{ Catch $(\mathrm{Kg})$} \\
\hline & & Time 18.30-22.30 & Time 24.00-04.00 \\
\hline \multirow[t]{2}{*}{1} & Hauling 1 & 249.6 & \\
\hline & Hauling 2 & & 377.5 \\
\hline \multirow[t]{2}{*}{2} & Hauling 1 & 569.89 & \\
\hline & Hauling 2 & & 947.81 \\
\hline \multirow[t]{2}{*}{3} & Hauling 1 & 611.2 & \\
\hline & Hauling 2 & & 811.8 \\
\hline \multirow[t]{2}{*}{4} & Hauling 1 & 500.3 & \\
\hline & Hauling 2 & & 673.2 \\
\hline \multirow[t]{2}{*}{5} & Hauling 1 & 400.19 & \\
\hline & Hauling 2 & & 524.51 \\
\hline \multirow[t]{2}{*}{6} & Hauling 1 & 509.02 & \\
\hline & Hauling 2 & & 753.98 \\
\hline \multirow[t]{2}{*}{7} & Hauling 1 & 528.82 & \\
\hline & Hauling 2 & & 695.88 \\
\hline \multirow[t]{2}{*}{8} & Hauling 1 & 449.1 & \\
\hline & Hauling 2 & & 686.4 \\
\hline \multirow[t]{2}{*}{9} & Hauling 1 & 404.7 & \\
\hline & Hauling 2 & & 637.1 \\
\hline \multirow[t]{2}{*}{10} & Hauling 1 & 265 & \\
\hline & Hauling 2 & & 455 \\
\hline
\end{tabular}


pengulangannya (Table 2). Hasil tangkapan paling banyak pada jam 18.30-22.30 terjadi pada trip ke-3 dengan berat hasil tangkapan sebesar $611,2 \mathrm{Kg}$, dan hasil tangkapan paling sedikit terjadi pada trip ke-1 yaitu sebesar 249,6 Kg. Hasil tangkapan terbanyak pada jam 24.00-04.00 terjadi pada trip ke-2 yaitu sebesar 947,81 $\mathrm{Kg}$ dan hasil tangkapan paling sedikit terjadi pada trip ke-1 yaitu sebesar 377,5 Kg. Total hasil tangkapan pada jam 18.3022.30 sebesar $4487,82 \mathrm{Kg}$ dan total hasil tangkapan pada jam 24.00-04.00 sebesar $6563,18 \mathrm{Kg}$.

Penelitian yang telah dilakukan menunjukkan bahwa hasil tangkapan didominasi oleh ikan teri. Hal ini dikarenakan ikan teri tergolong jenis ikan yang menyukai cahaya (phototaxis). Menurut Sudirman et al. (2004), ikan teri cenderung memilih intensitas cahaya yang lebih tinggi, cenderung berada di permukaan air, dan cepat memasuki areal bagan, sehingga tidak dibutuhkan waktu yang lama untuk melakukan proses adaptasi cahaya secara sempurna. Namun masih diperlukan lama waktu pencahayaan bagi ikan teri untuk beradaptasi secara sempurna. Ikan teri masuk ke catchcable area bagan karena faktor ketertarikan terhadap cahaya secara langsung (tertarik oleh cahaya lalu berkumpul) maupun tidak langsung (karena ada cahaya dan plankton yang menarik ikan teri berkumpul untuk mencari makan). Jumlah hasil tangkapan pada jam 18.3022.30 dan jam 24.00-04.00 dapat dilihat pada Figure 3.

Berdasarkan Figure 3 dapat diketahui bahwa hasil tangkapan alat tangkap bagan perahu pada waktu penangkapan jam 24.00-04.00 lebih banyak dibandingkan dengan waktu penangkapan jam 18.3022.30. Hasil ini sejalan dengan penelitian yang telah dilakukan oleh Fauziyah et al. (2013) bahwa rataan hasil tangkapan tertinggi diperoleh pada waktu Hauling tengah malam (00.00-02.59 WIB), di mana hasilnya mencapai 2-3 kali lipat dari periode sebelum maupun sesudah tengah malam pada kategori total hasil tangkapan dan tangkapan ikan teri. Hasil ini juga selaras dengan penelitian Zulfia (1999), dimana hasil penelitiannya menunjukkan bahwa berat hasil tangkapan bagan sesudah tengah malam (jam 24.00-06.00 WIB) lebih besar jika dibandingkan dengan sebelum tengah malam (jam 18.00-24.00 WIB).

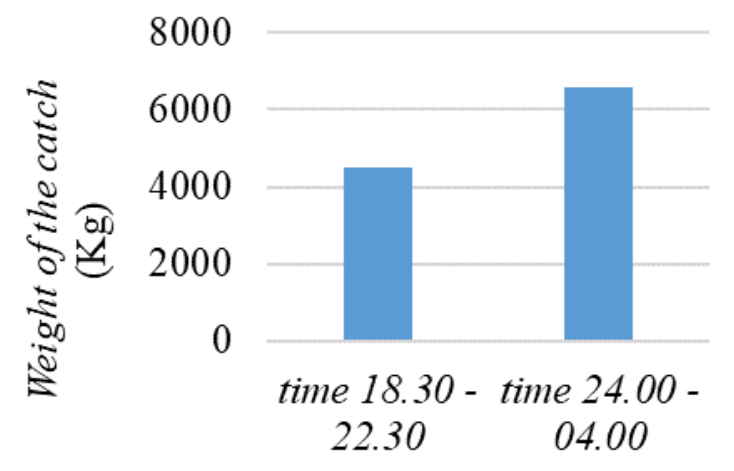

Figure 3. Weight graph of catches over time.

\subsection{Perbedaan Lama Waktu Penarikan terhadap Hasil Tangkapan}

Hasil mengenai lama waktu penarikan terhadap hasil tangkapan dapat dilihat pada Table 3. Berdasarkan Table 3 dapat dilihat bahwa dalam 10 kali trip pengambilan sampel, hasil yang diperoleh berbedabeda di setiap trip penangkapan. Mengenai perbedaan lama penarikan terhadap hasil tangkapan terlihat bahwa hasil tangkapan terbanyak pada lama penarikan 20-27,5 menit yaitu pada trip ke-2 sebanyak 947,81 $\mathrm{Kg}$ dan hasil tangkapan paling sedikit yaitu pada trip ke-4 sebanyak 500,3 Kg. Hasil tangkapan terbanyak pada lama penarikan 27,6-35 menit, yaitu pada trip ke-8 sebanyak $686,4 \mathrm{Kg}$ dan hasil tangkapan paling sedikit yaitu pada trip ke-1 sebanyak 249,6 Kg. Menurut Mohammad et al. (1999), penarikan tersebut harus dilakukan dengan kecepatan yang memungkinkan ikan tidak melarikan diri dari daerah tangkapan (catchable area) jaring bagan. Kecepatan penarikan jaring merupakan salah 
Table 3. Difference in withdrawal duration for catches.

\begin{tabular}{|c|c|c|c|}
\hline \multirow{2}{*}{ Trip } & \multirow{2}{*}{ Repitition } & \multicolumn{2}{|c|}{ Catch $(\mathrm{kg})$} \\
\hline & & 20-27.5 minute & 27.6-35 minute \\
\hline \multirow[t]{2}{*}{1} & Setting 1 & & 249.6 \\
\hline & Setting 2 & & 377.5 \\
\hline \multirow[t]{2}{*}{2} & Setting 1 & & \\
\hline & Setting 2 & 947.81 & \\
\hline \multirow[t]{2}{*}{3} & Setting 1 & 611.2 & \\
\hline & Setting 2 & 811.8 & \\
\hline \multirow[t]{2}{*}{4} & Setting 1 & 500.3 & \\
\hline & Setting 2 & 673.2 & \\
\hline \multirow[t]{2}{*}{5} & Setting 1 & & 400.19 \\
\hline & Setting 2 & & 524.51 \\
\hline \multirow[t]{2}{*}{6} & Setting 1 & 509.02 & \\
\hline & Setting 2 & 753.98 & \\
\hline \multirow[t]{2}{*}{7} & Setting 1 & 528.82 & \\
\hline & Setting 2 & 695.88 & \\
\hline \multirow[t]{2}{*}{8} & Setting 1 & & 449.1 \\
\hline & Setting 2 & & 686.4 \\
\hline \multirow[t]{2}{*}{9} & Setting 1 & & 404.7 \\
\hline & Setting 2 & & 637.1 \\
\hline \multirow[t]{3}{*}{10} & Setting 1 & & 265 \\
\hline & Setting 2 & & 455 \\
\hline & & 6601.9 & 4449.1 \\
\hline
\end{tabular}

satu faktor yang menunjang keberhasilan pengoperasian bagan, karena kecepatan penarikan yang terlalu lambat atau terlalu cepat dapat mengakibatkan ikan meloloskan diri dari daerah tangkapan sebelum sempat terangkat ke permukaan air. Jumlah hasil tangkapan pada lama penarikan 2027,5 menit dan 27,6-35 menit dapat dilihat pada Figure 4.

Berdasarkan Figure 4 dapat dilihat bahwa hasil tangkapan bagan perahu pada lama penarikan 20-27,5 menit jauh lebih banyak dibandingkan dengan hasil tangkapan pada lama penarikan 27,6-35 menit. Pada saat berlangsungnya proses penarikan bagan perahu yang semakin cepat, maka ikan yang tertangkap semakin banyak dengan tingkat kelolosan ikan relative kecil; sebaliknya bila waktu penarikan bagan perahu yang semakin lama, maka ikan yang tertangkap semakin sedikit dengan tingkat kelolosan ikan relatif besar saat jaring ditarik oleh roller. Menurut Mohammad et al. (1999), kecepatan hauling yang tinggi sangat diperlukan pada operasi penangkapan bagan, dimana keberhasilan penangkapan tergantung pada kecepatan dan waktu penarikan jaring saat gerombolan ikan terkumpul pada daerah penangkapan (cactcable area). Bila terlalu

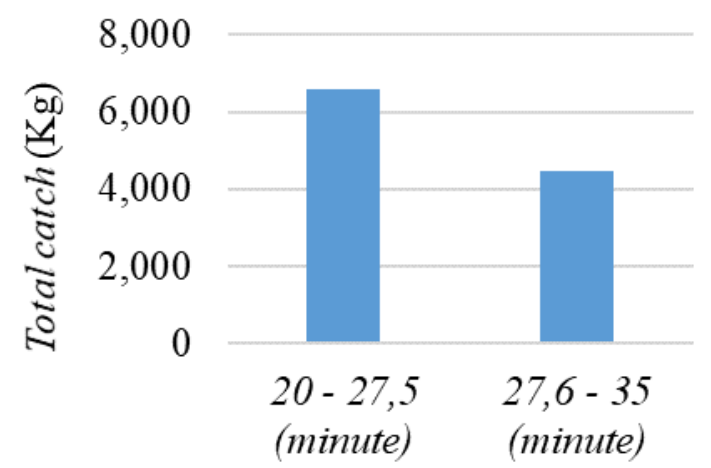

Figure 4. Weight graph of catches on withdrawal time. 
lama penarikan atau pengangkatan jaring bagan, maka peluang gerombolan ikan untuk meloloskan diri dari daerah penangkapan akan semakin besar.

Hasil Analisis Varians pada Uji F (Simultan) didapatkan nilai $\mathrm{F}$ hitung $24,173>$ F tab 3,591 dan Sig. 0,000< 0,05 maka tolak $\mathrm{H}_{0}$ atau waktu operasi (X1) dan lama penarikan (X2) secara simultan berpengaruh nyata terhadap hasil tangkapan (Y). Nilai yang diperoleh pada analisis varian berdasarkan Uji t (Parsial) diketahui untuk variabel waktu operasi diperoleh nilai t hitung 4,826>t tabel 2,100 dan nilai Sig. $0,004<0,00$ maka tolak $\mathrm{H}_{0}$, sehingga waktu operasi sebelum dan setelah jam 12 malam, berpengaruh nyata terhadap hasil tangkapan. Variabel lama penarikan: $t$ hitung 5,006>t tabel 2,1009 dan nilai Sig.0,09<0,00 maka tolak $\mathrm{H}_{0}$, sehingga lama penarikan juga berpengaruh nyata terhadap hasil tangkapan.

Menurut Sugiyono (2013), pedoman interpretasi nilai $\mathrm{R}$ terbagi dalam 5 kategori yakni sangat rendah $(0,0-0,19)$, rendah $(0,2-0,39)$, sedang $(0,4-0,59)$, kuat $(0,6-$ $0,79)$, dan sangat kuat $(0,8-1,0)$. Hal ini menjadi dasar penilaian terhadap hasil analisis Regresi korelasi dan determinasi dimana diperoleh nilai $\mathrm{R}$ 0,86 yang menunjukkan korelasi sangat kuat antara hasil tangkapan sebagai variabel terikat dengan waktu operasi dan lama penarikan sebagai variabel bebas. Nilai Koefisien determinasi (R2) diperoleh sebesar 0,74 artinya, hasil tangkapan dapat dijelaskan $74 \%$ oleh waktu operasi dan lama penarikan, sedangkan $26 \%$ dijelaskan oleh faktor lain yang tidak masuk dalam variabel penelitian.

\section{KESIMPULAN}

Berdasarkan Penelitian yang telah dilakukan, dapat ditarik kesimpulan bahwa hasil tangkapan pada alat tangkap bagan perahu diperoleh target tangkapan terdiri dari 1 spesies yaitu ikan Teri (Stolephorus spp.) dengan berat $5.939 \mathrm{Kg}$. Hasil tangkapan bycatch terdiri dari 5 spesies dengan berat total $5.190 \mathrm{Kg}$, di mana hasil tangkapan ikan Tembang/Juwi (S. gibbosa) sebanyak 3.851 Kg, Cumi-Cumi (Loligo sp.) sebanyak 89,5 $\mathrm{Kg}$, Ikan Kembung (R. negletus) sebanyak $462 \mathrm{Kg}$, Ikan Selar (S. leptolepis) sebanyak $845 \mathrm{Kg}$, dan Ikan Layur (T. lepturus) sebanyak $64,5 \mathrm{Kg}$; Hasil analisis statistik menunjukkan bahwa variabel waktu penangkapan berpengaruh nyata terhadap hasil tangkapan. Total hasil tangkapan yang diperoleh bagan perahu pada jam 18.30-22.30 sebesar 4.487,82 $\mathrm{Kg}$ dan total hasil tangkapan pada jam 24.00-04.00 sebesar $6.563,18 \mathrm{Kg}$, di mana semuanya didominasi oleh jenis ikan Teri (Stolephorus spp.). Variabel lama penarikan juga berpengaruh nyata terhadap hasil tangkapan, di mana hasil tangkapan bagan perahu dengan lama penarikan 20-27,5 menit diperoleh total tangkapan sebesar $6.601,9 \mathrm{Kg}$, dan lama penarikan 27,6-35 menit diperoleh hasil tangkapan total sebesar 4.449,1 Kg.

\section{UCAPAN TERIMA KASIH}

Penulis mengucapkan terimakasih banyak kepada Departemen Perikanan Tangkap Fakultas Perikanan dan Ilmu Kelautan Universitas Diponegoro Semarang dan LPPM Universitas Diponegoro Semarang.

\section{DAFTAR PUSTAKA}

Dinas Kelautan dan Perikanan. 2012. Identifikasi Kerusakan dan Perencanaan Rehabilitasi Pantura Jawa Tengah. Kementerian Kelautan dan Perikanan Satuan Kerja Dinas Kelautan dan Perikanan Provinsi Jawa Tengah.

Dinas Perikanan dan Kelautan Kabupaten Demak. 2019. Laporan Tahunan Dinas Perikanan dan Kelautan Kabupaten Demak. 2014-2018.

Fauziyah, F. Supriyadi, K. Saleh, \& Hadi. 2013. Perbedaan waktu hauling 
bagan tancap terhadap hasil tangkapan di Perairan Sungsang Sumatera Selatan. J. Lahan Suboptimal, 2(1): 50-57. http://doi.org/10.33230/JLSO.2.1.20 13.36

Hasan. 2008. Uji coba penggunaan lampu lacuba tenaga surya pada bagan apung terhadap hasil tangkapan ikan di Pelabuhan Ratu Jawa Barat. J. Sains dan Teknologi Indonesia, 2(3), 11-18.

Julian D. 2014. Uji coba penangkapan ikan dengan bagan tancap menggunakan lampu led (Light Emitting Diode). [SKRIPSI]. Bogor: Departemen Pemanfaatan Sumberdaya Perairan, Fakultas Perikanan dan Ilmu Kelautan, Institut Pertanian Bogor. $41 \mathrm{p}$.

Junaidi. 2001. Bagan Perahu di Labuan Bajo, Flores: Rancang Bangun dan Metode Pengoperasiannya. [Skripsi] (tidak di publikasikan). Bogor: Departemen Pemanfaatan Sumberdaya Perikanan, Fakultas Perikanan dan Ilmu Kelautan, Institut Pertanian Bogor, Bogor. 66 p.

Manggabarani AHS. 2011. Perbandingan Hasil Tangkapan Bagan Tancap Berdasarkan Waktu Hauling pada Jarak yang Berbeda dari Pantai di Desa Punagaya Kabupaten Jeneponto. [SKRIPSI]. Makassar: Jurusan Perikanan, Fakultas Ilmu Kelautan dan Perikanan, Universitas Hasanuddin. $41 \mathrm{p}$.

Mohammad, I., W. Mawardi, \& Darmawan. 1999. Pengaruh kecepatan penarikan jaring (hauling) terhadap hasil tangkapan bagan apung di Pelabuhan Ratu. Buletin PSP, VIII(1): 45-54. https://repository.ipb.ac.id/handle/1 23456789/66937

Subani, W. \& H.R. Barus. 1989. Alat penangkapan ikan dan udang laut di Indonesia (Fishing Gears for marine Fish and Shrimp in Indonesia). No. 50 Tahun 1988/1989. Edisi Khusus, Edisi Khusus. Jurnal Penelitian Perikanan Laut (Journal of marine Fisheries Research). Balai Penelitian Perikanan Laut, Badan Penelitian dan Pengembangan Pertanian, Departemen Pertanian. Jakarta. 248 p.

Sudirman, \& A. Mallawa. 2004. Teknik Penangkapan Ikan. PT. Rineka Cipta. Jakarta.

Sudirman, M.S. Baskoro, A. Purbayanto, D.R. Monintja, W. Rismawan, \& T. Arimoto. 2004. Respon retina mata ikan teri (stolephorus insularis) terhadap cahaya dalam proses penangkapan pada bagan Rambo. Bulletin Torani, 14(3): 1-14.

Sugiyono. 2007. Metode Penelitian Kuantitatif Kualitatif dan R\&D. Bandung: Alfabeta.

Sugiyono. 2013. Metode Penelitian Pendidikan Pendekatan Kuantitatif, Kualitatif, dan R\&D. Bandung: Alfabeta.

Sumanto. 2014. Teori dan Metode Aplikasi Metode Penelitian. Yogyakarta: CAPS. 78 p.

Wibowo, B.A., H. Boesono, \& A.B. Adhitomo. 2012. Analisis kebijakan terhadap aktivitas penangkapan ikan nelayan Karimunjawa Kabupaten Jepara. J. Saintek Perikanan, 8(1): $37-45$.

https://ejournal.undip.ac.id/index.ph $\mathrm{p} /$ saintek/article/viewFile/6767/553 3

Wisudo, S.H, S. Akiyama, H. Sakai, \& T. Arimoto. 2001. Capture process of liftnet monitored by echo sounder and sonar. fishing technologi manual series! light fishing in Japan ad Indonesia. TUF JSPS International Vol. 11. Dept. Of Fisheries Resources Utilization, IPB. 5-16 pp.

Zulfia. 1999. Pengaruh perbedaan waktu 
hauling terhadap hasil tangkapan bagan diesel di Perairan Carocok, Received : 14 September 2020 Kabupaten Pesisir Selatan, Propinsi Reviewed : 9 October 2020 Sumatera Barat [skripsi]. Bogor: Accepted :20 December 2020 FPIK-IPB. 
